\title{
Een onderzoek naar de organisatie van de Gentse gemeentepolitie 1848-1914. ${ }^{1}$
}

\author{
Isolde VANDEWALLE
}

De politie van de Belgische gemeenten werd zeer weinig bestudeerd; alleen het feit dat men in de algemene politieke geschiedenissen van België vergeefs zoekt naar het trefwoord gemeentepolitie, benadrukt deze vaststelling.

De koploper van de werken die de gemeentepolitie behandelen is het doctoraat van Cyrille Fijnaut, Opdat de macht een toevlucht zij ? Een historische studie van het politieapparaat als politieke instelling. Fijnaut bestudeert de evolutie van het moderne politieapparaat vanaf de Franse revolutie tot en met de Tweede Wereldoorlog en benadrukt daarbij de nationalisering van het apparaat.

Zeer recent is het werk van Lode Van Outrive, Yves Cartuyvels en Paul Ponsaers, Les polices en Belgique. Histoire socio-politique du système policier de 1794 à nos jours. Naast enkele artikels verschenen : Geschiedenis van het Brusselse politiekorps (1831-1914). van Luc Keunings waarin de organisatie van de Brusselse gemeentepolitie behandeld wordt, Histoire de la police liègeoise de 1795 a nos jours. van J. Erose en een onuitgegeven licentiaatsverhandeling van Geert Foutré, Een onderzoek naar de werking van het Belgisch politioneel apparaat. 1830-1848. ${ }^{2}$

1 Gebaseerd op VANDEWALLE ISOLDE, In naam van de onrust. Een onderzoek naar de organisatie van de Gentse gemeentepolitie 1848-1914. Gent, onuitgegeven lic. verh. o.l.v. Prof. H. Balthazar, 1991-1992.

2 FINAUT (C.), Opdat de macht een toevlucht zij ? Een historisch studie van het politieapparaat als politieke instelling. Kluwer, 1979.

VAN OUTRIVE (L.), CARTUYVELS (Y.) en PONSAERS (P.), Les polices en Belgique. Histoire socio-politique du système policier de 1794 d nos jours. Bruxelles, 1991. Dit jaar werd het in het Nederlands uitgegeven onder de titel : Sire ik ben ongerust, Geschiedenis van de Belgische politie 1794-1991. Leuven 1992.

KEUNINGS (L.), De geschiedenis van het Brusselse politiekorps (1831-1914). In: Gemeentekrediet van België. 1989, nr. 169, pp. 3-31.

BROSE (J.), Histoire de la police liègoise de 1795 d nos jours. Liège, 1971.

FOUTRE (G.), Een onderzoek naar de werking van het Belgisch politionele apparaat. 1830-1848. Gent, onuitgegeven lic. verh., 1984-1985. 


\section{VANDEWALLE}

Op dit werk van Foutré aansluitend, ging ik dieper graven in de Gentse situatie, meer bepaald de gemeentepolitie. Op basis van archiefmateriaal ${ }^{3}$ en gedrukte bronnen ${ }^{4}$ kon ik mij een beeld vormen van het personeel, de benoemingen, de lonen en vergoedingen, het uniform, de discipline...

Vooraleer daar dieper op in te gaan is het interessant om even stil te staan bij de historiek van de gemeentepolitie en de rol van de verschillende autoriteiten die er zeggenschap over hebben.

\section{A. HISTORIEK EN WETTELIJKE STRUCTUUR}

Toen de Voorlopige Regering op 4 oktober 1830 de onafhankelijkheid van België uitriep, stond ze voor een enorme opdracht.

Naast de benoeming van een commissie voor een voorontwerp van de grondwet en de instelling van het Nationaal Congres waren er nog heel wat andere zaken die moesten geregeld worden, ondermeer de vorming van een Belgisch politieapparaat.

Dit apparaat - waar gemeentepolitie, burgerwacht, rijkswacht en leger, deel van uitmaken - werd met het Franse voorbeeld voor ogen tot stand gebracht. De wortels van de Belgische politiediensten liggen immers in de periode waarin België bij Frankrijk geannexeerd was (1795-1814).

$\mathrm{Na}$ de officiële bekrachtiging van de aanhechting van België bij Frankrijk op 30 september 1795 werd de Franse wetgeving toegepast op het Belgisch grondgebied, ook inzake de plaatselijke politie.

De belangrijkste decreten waren het decreet van 14 december 1789 en dat van 16-24 augustus 1790.

In het eerste decreet werd een eenvormig stelsel ingevoerd voor alle gemeenten van het rijk. Het regelde de bevoegdheden van de 'municipalités' waarbij ook de gemeentepolitie hoorde. Artikel 50 bepaalde dat het gemeentebestuur moest zorgen voor een 'bonne police'.5

In het tweede decreet werden de bevoegdheden van de 'municipalités' met betrekking tot de gerechtelijke organisatie vastgelegd. Titel XI verduidelijkte de opdracht van 'bonne police' in een aantal artikels.

De artikels van titel XI vormen nog steeds de basis van de gemeentepolitie aangezien de gemeentewet van 1836 de opdracht van de politie niet

3 Geraadpleegde archieven : Rijksarchief Gent (R.A.G.) : Provinciaal bestuur 1830-1850, 1850-1870; Rijksarchief Beveren-Waas (R.A.B.W.) : Provinciaal bestuur 1870-1914; stadsarchief Gent (S.A.G.) : Gemeenteblad tot 1867, Reeks R, Reeks XVI.

4 Gedrukte bronnen : Universiteitsbiblioteek Gent : Wegwijzer van de stad Gent, Gemeenteblad 1867-1914, Pasinomie, Pandectes.

5 Dit artikel werd in België -samen met artikel 1, 14, 15, 50, 51, 59, 60 en 61van kracht door het besluit van 10 december 1795 (19 frimaire jaar IV). De artikels 50 en 51 bleven van kracht in het onafhankelijke België. 


\section{EEN ONDERZOEK NAAR DE ORGANISATIE VAN DE GENTSE POLITIE}

vermeldt. ${ }^{6}$ De taak van de 'bonne police' bestond uit het verzekeren van vlot en veilig verkeer, het bestraffen van verstoringen van de openbare rust, het handhaven van de orde bij festiviteiten, op markten.., het controleren van de maten en gewichten, het treffen van maatregelen bij brand, besmettelijke ziekten.. en het verhinderen dat geesteszieken en dolle dieren ongelukken zouden veroorzaken. Een andere opdracht, het uiteendrijven van samenscholingen, werd in een afzonderlijk artikel meegedeeld. De taak van de gemeentepolitie valt uiteen in een administratieve en een gerechtelijke.

De taken van de Belgische politie werden dus uiteengezet in deze decreten. De bevoegdheden van de overheden met betrekking tot de gemeentepolitie vindt men voornamelijk terug in de gemeentewet en de provinciewet van 1836.

Een belangrijke rol inzake de bevoegdheden wordt gespeeld door de gemeentelijke overheid, meer bepaald door de burgemeester. Als hoofd van de politie organiseert de burgemeester het korps en regelt hij de dienst. Hij is niet alleen belast met de uitvoering van de politiereglementen maar ook met het toezicht op de lokale politie. Hij benoemt en schorst het personeel van het lagere en het hogere kader (het hogere kader met de goedkeuring van de gouverneur voor de adjuncten en de minister voor de commissarissen). De burgemeester kan echter niet alleen beslissen, ook de gemeenteraad speelt een rol bij de organisatie van de gemeentepolitie.

Zowel burgemeester als gemeenteraad staan op de ladder van de bestuurlijke hiërarchie een trap lager dan de gouverneur.

De gouverneur, die optreedt als tussenpersoon tussen de gemeenten en de nationale overheid, wordt zowel direct als indirect betrokken bij de gemeentepolitie. Rechtstreeks is hij betrokken bij benoemingen en schorsingen van adjunct-commissarissen en commissarissen aangezien hij zijn goedkeuring moet verlenen over de door de gemeenteraad voorgestelde kandidaat. Hij kan het politiepersoneel ook machtigen om als hulp in andere gemeenten hun taken uit te voeren.

Onrechtstreeks participeert de gouverneur via het bestuurlijk toezicht.

De top van de bestuurlijke hiërarchie wordt bezet door de minister van Binnenlandse Zaken. Hij speelt een belangrijke rol bij de oprichting of opheffing van de korpsen, bij de oprichting of opheffing van de commissariaten en bij de benoeming of het ontslag van de commissarissen. De justitie, meer bepaald het ministerie van justitie en het openbaar ministerie, is formeel niet betrokken bij het dagelijks beheer van een gemeentelijk korps. De justitie laat zich ook niet in met het algemeen beheer.

6 MALVOZ (L.), De plaatselijke instellingen in België van het einde van het Ancien régime tot de gemeentewet van 1836. In : Gemeentekrediet van België, 158, XL, oktober 1986, pp. 9-10. 


\section{VANDEWALLE}

De minister van justitie en de procureur-generaal houden zich wel bezig met de benoemingen van de hoofdcommissaris en de commissarissen.

De gemeentepolitie is verbonden met het ministerie van justitie op het vlak van de vreemdelingenkwesties, het gemeentelijk strafregister en de politieke en criminele informatie.

Tenslotte impliceert de 'link' met justitie dat de politieke en criminele inlichtingendienst van dit ministerie in contact staat met de gemeentelijke korpsen.

\section{B. DE ORGANISATIE VAN DE GENTSE GEMEENTEPOLITIE}

Vooraleer ik dieper op de organisatie van het korps na 1848 zal ingaan, wil ik toch even de situatie weergeven in de periode 1830-1848.7

Het Gentse politiekorps bestond uit 1 directeur, 6 commissarissen en 18 agenten. De stad was opgedeeld in 5 politiewijken. Aan het hoofd van zo'n wijk stond een politiecommissaris die met de hulp van ongeveer 4 agenten de politietaken uitvoerde. Hun opdracht bestond uit patrouilleren en de controle van verdachte kroegen en bordelen. Vaak kregen ze van de burgemeester de opdracht om informatie te verzamelen over bepaalde verdachte personen en vanaf 1839 hielden ze ook de ex-gedetineerden in het oog. Toen in 1842 de paspoortcontrole aan de grenzen werd opgeheven, moest deze taak worden overgenomen door de stedelijke overheid die de politie ermee belastte.

Dagelijks werden verslagen opgemaakt van de gebeurtenissen (twisten, diefstal...) die hadden plaatsgevonden in de wijken. De verslagen van de verschillende wijken werden verzameld door de hoofdcommissaris. De burgemeester verzond maandelijks (later om de twee maand) een algemeen politieverslag naar de gouverneur waarin de toestand van de stad werd uiteengzet.

Uit de inleiding van een overzicht van maatregelen ten bate van de Gentse katoenindustrie blijkt dat het Gentse politiekorps als onderbemand werd beschouwd. ${ }^{8}$

Het gebrek aan manschappen kwam zeer sterk naar voor bij de onlusten in het jaar 1848. De gemeentepolitie kon met moeite haar taak voor de openbare veiligheid volbrengen en was niet in staat om het oproer alleen te onderdrukken. De burgerwacht, de gendarmerie en de brandweer moesten de gemeentepolitie ter hulp komen.

In april 1848 werd door het ministerie van Justitie en Binnenlandse zaken dan ook aangedrongen op een reorganisatie. $\mathrm{Zij}$ stelden voor om het effectief

7 FOUTRE (G.), Op.cit. pp.46-52.

8 WOUTERS (H.), Documenten betreffende de geschiedenis der arbeidersbeweging (1831-1853). Leuven-Parijs, 1963, nr. 1263, pp.895. 


\section{EEN ONDERZOEK NAAR DE ORGANISATIE VAN DE GENTSE POLITIE}

te verhogen, onder elke commissaris een adjunct te plaatsen en de functie van hoofdcommissaris in te stellen. ${ }^{9}$

In de loop van 1848 werd het effectief verhoogd maar een grondige reorganisatie, volgens de ministeriële richtlijnen, werd door een commissie voorbereid. Hun rapport werd in september 1852 in de gemeenteraad voorgelezen. Na enkele kleine discussies werd het 'Règlement sur l'organisation de la police de la ville de Gand' aanvaard. Het reglement bestond uit vijf hoofdstukken en vierentwintig artikels. Het eerste behandelde de regelingen met betrekking tot het personeel, het tweede de benoemingen, het derde de lonen, het vierde de uniformen en insignes en het vijfde de tuchtmaatregelen. In de loop van de bestudeerde periode werden aan dit reglement wijzigingen aangebracht, vooral inzake de lonen en het aantal manschappen, maar de basis van de organisatie was gelegd. 10

De indeling van de onderwerpen gebeurt volgens het reglement.

\section{B.1. Het personeel}

Het eerste artikel bepaalde dat het personeel van de politie bestond uit een hoofdcommissaris, wijkcommissarissen, adjunct-commissarissen van 3 klassen, een opper-brigadier, brigadiers en agenten van 2 klassen.

De hoofdcommissaris, wijkcommissarissen en adjunct-commissarissen behoorden tot het hoger kader; de brigadiers en agenten maakten deel uit van het lager kader.

Deze samenstelling van het personeel bleef grotendeels ongewijzigd.

Wel waren er enkele veranderingen zoals het wegvallen van de klassen bij de adjunct-commissaris, de toevoeging van een 3 de klasse bij de agenten... De meest ingrijpende wijzigingen en ook de meest logische zijn deze in verband met het personeelsbestand.

\section{B.1.1. Het effectief}

\section{De periode 1848-1860}

In 1848 werkten vier personeelsleden op het hoofdbureel aan de Poeljemarkt. Het was geopend van 9.00 uur tot 15.00 uur. De permanentie was op de Botermarkt. In het hoofdbureel werkten het hoofd van de politie, een commies, de commissaris van Zeevaart en Ontvanger van het Loodswezen en de Hoofd-brigadier van de politieagenten.

9 Brieven aan de burgemeester van de gouverneur op 22 maart 1848, 8 april 1848,13 april 1848, van de burgemeester naar de gouverneur in april 1848. S.A.G. politiearchief Reeks $\mathbf{R}$.

10 Gemeenteblad. 1852, pp.119. 


\section{VANDEWALLE}

Er waren 5 commissarissen, die elk een wijk toegewezen kregen, en 2 adjunct-commissarissen. Het lager kader bestond uit 21 brigadiers en agenten. ${ }^{11}$

$\mathrm{Na}$ de troebelen van het jaar 1848 werd het korps uitgebreid. In de gemeenteraad van 15 juli 1848 besloot men om een nieuwe functie van commissaris in te stellen, 5 adjunct-commissarissen van 2de klasse te benoemen en 7 agenten aan te stellen waardoor men er 33 kon tellen. ${ }^{12}$ In de wegwijzer, waar de feitelijke sterkte van het korps wordt weergegeven, kan men de uitbreiding in de praktijk vaststellen. Er wordt echter geen melding gemaakt van een zesde commissaris en de politieagenten bereiken het aantal 33 niet.

Niettemin kende het korps een enorme uitbreiding. Er werden 5 adjunctcommissarissen van 2de klasse en 10 agenten benoemd. Van 1849 tot en met 1853 (het nieuwe reglement werd toen daadwerkelijk toegepast) bestond het korps uit de personeelsleden van het hoofdbureel, 7 adjunct-commissarissen en ongeveer 30 agenten. ${ }^{13}$

Het reglement van 1852 verhoogde het aantal personeelsleden en de functie van hoofdcommissaris werd ingesteld.

Daarnaast kende de gemeentepolitie 5 wijkcommissarissen, 12 adjunctcommissarissen (2 van 1ste klasse, 5 van 2de klasse en 5 van 3de klasse), 1 hoofdbrigadier, 5 wijkbrigadiers en 45 agenten ( 12 van 1ste klasse en 33 van 2de klasse).

Het hoofdbureel werd voortaan het middenbureel genoemd en bevond zich in het stadhuis. In dit bureel werkten de hoofdcommissaris en 2 adjunctcommissarissen.

In de gemeenteraadszitting van 17 februari 1855 werd een wijziging in het politiereglement aangebracht. ${ }^{14} \mathrm{Er}$ zou geen melding meer gemaakt worden van een hoofdcommissaris. Dit gebeurde nadat een aantal inwoners een verzoek hadden ingediend tot opheffing van het middenbureel omdat zij dit onwettig achtten. De commissie van betwisting kwam tot de vaststelling dat zij vreesden dat de hoofdcommissaris een soort politiedirecteur of een buitengewone commissaris was. Daarom besloot men om in plaats van 5 commissarissen met 1 hoofdcommissaris te spreken van 6 commissarissen waarvan de burgemeester jaarlijks een commissaris zou aanduiden waaraan de 5 andere ondergeschikt waren. ${ }^{15}$

In feite zou er dus nog steeds een hoofdcommissaris zijn.

1 Wegwijzer. 1848, pp. 216-217.

Gemeenteblad. 1848, pp.128.

31 in 1849,30 in $1850-1852,32$ in 1853.

Gemeentblad. 1855, pp.14, n॰54.

Gazette van Gent. 17/02/1855. 


\section{EEN ONDERZOEK NAAR DE ORGANISATIE VAN DE GENTSE POLITIE}

In 1858 werden de functie van adjunct-commissaris van 3de klasse en die van hoofd-brigadier opgeheven. In de plaats van deze beide kwam een adjunct-commissaris opzichter van de werkelijke dienst die de rang kreeg van adjunct-commissaris van 3 de klasse.

Tot en met 1860 was de Gentse gemeentepolitie op die wijze samengesteld.

\section{0-1890}

Onder invloed van de afschaffing van de octrooien kwam men in 1860 tot een reglementswijziging. Er kwamen drie artikels bij en een aantal artikels werd veranderd. 16

Het personeel werd als volgt samengesteld : 6 commissarissen, waarvan 1 door de burgemeester als chef werd aangeduid, 9 adjunct-commissarissen, 1 adjunct-commissaris die opzichter van de dienst was, 20 politiebrigadiers, 17 agenten van de 1ste klasse en 42 van 2 de klasse.

Men sprak niet meer van klassen bij de adjunct-commissarissen. Opvallend is de stijging van 5 naar 20 brigadiers. In de commentaren van het gemeenteblad kan men lezen dat het niet volstond om over een voldoende aantal agenten te beschikken. Het was noodzakelijk om deze regelmatig te controleren en er toezicht op uit te oefenen. Het aantal agenten werd eveneens sterk opgedreven.

Een zesde commissariaat werd in 1867 ingesteld waarvoor een commissaris werd benoemd. Zo kwam men tot 6 wijkcommissarissen en 1 hoofdcommissaris. De hoofdcommissaris werd weer afzonderlijk vermeld. In 1882 werd eveneens de oprichting van een nieuw commissariaat doorgevoerd met de daaraan gepaard gaande benoeming van een commissaris.

Het aantal adjunct-commissarissen veranderde weinig in de periode 1860 $1890{ }^{17}$ evenals het aantal brigadiers. ${ }^{18}$

In de wegwijzer telt men niet 49 agenten, zoals werd vastgelegd in het reglement, maar 48 . Hun aantal was meer dan verdubbeld in 30 jaar tijd. In 1890 maakten 103 agenten deel uit van het korps. 19

\section{0-1914}

In 1890 werden grondige wijzigingen in het lager kader van het personeel doorgevoerd. Er werden 5 nieuwe plaatsen van brigadier ingesteld. Zes

16 Gemeenteblad. 15/09/1860, pp124-127.

17 Van 9 in 1860 naar 10 in 1873,12 in 1877,13 in 1883, om vanaf 1883 tot 1890 uit 11 te bestaan.

1820 in 1861,19 in 1876,21 in 1881

1964 in 1868,76 in 1876, 83 in 1881, 98 in 1884,103 in 1888. 


\section{VANDEWALLE}

nieuwe ambten van agenten van tweede klasse werden opgericht, 12 agenten van 2 de klasse werden agenten van 1ste klasse, waardoor men nu 80 agenten van 2de klasse en 42 agenten van 1ste klasse kreeg, een totaal van 122 agenten. Deze aantallen komen overeen met de sterkte weergegeven in de wegwijzer, maar niet de verhouding agenten 1ste/2de klasse.

In de wegwijzer is ook sprake van 10 brigadiers 'judicaires'.

Vanaf 1895 waren er agenten van 3de klasse.

Het korps telde in de periode 1896-1904 ongeveer 140 agenten, van 1905 tot 1908 een147-tal en van 1909 tot 1913 een 151 tot 154. In 1914 bestond het korps uit 187 agenten.

Het aantal brigadiers bleef tot en met 1913 hetzelfde, nl. 25. In 1914 werden er drie brigadiers aan toegevoegd.

De adjunct-commissarissen werden in 1894 (besloten in 1892) van 11 op 14 gebracht. Hun aantal varieert van 15 tot $17 . .^{20}$

In 1905 werd een nieuw commissariaat opgericht waardoor men van 7 naar 8 commissarissen ging met daarbij de hoofdcommissaris.

In 1914 waren er 11 comissarissen aangezien er in 1911 drie nieuwe politiewijken ingericht werden.

Het is duidelijk dat het korps zich steeds maar uitbreidde. Deze expansie gebeurde zowel in het hoger als in het lager politiekader. Hoewel het korps voortdurend groeide kan men toch drie momenten aanduiden waarop het apparaat spectaculair vergrootte, meer bepaald 1848, 1860 en 1890.

Na een studie van het optreden van de politie in de pers en de correspondentie tussen de verschillende overheden werden de redenen tot uitbreiding duidelijk. Voor 1848 werd het reeds gezegd, meer bepaald het tekort aan manschappen en het gebrekkig optreden van de politie bij de woelingen in 1848. In 1860 was de uitbreiding te wijten aan de afschaffing van de octrooien aan de stadspoorten. De uitbreiding in de jaren ' 90 van de vorige eeuw had te maken met de vele stakingen die uitbraken en de voortdurende onrust die er heerste.

\section{B.1.2. De functies van de verschillende leden van de politie}

Een beschrijving van de taken en functies van de verschillende personeelsleden dringt zich eveneens op. De beschrijving gebeurt op basis van de instructies die het reglement van 1860 vergezelden. De artikels van het eerste hoofdstuk van het reglement van 1852 werden in dit deel verwerkt.

2015 van 1896-1899, 16 van 1900-1905, 15 van 1906-1908,16 in 1909, 17 in 1912-1913 en 15 in 1914. 


\section{B.1.2.1. Het middenbureel en de hoofdcommissaris}

Het middenbureel, gevestigd in het stadhuis, werd geleid door de hoofdcommissaris. Het algemeen bestuur van het personeel van de politie werd aan hem toevertrouwd. ${ }^{21}$

\section{B.1.2.2. Toezicht op de wijken}

Voor het toezicht op de wijken werd een onderscheid gemaakt tussen de dienst van de agenten en de dienst van de wijkcommissarissen. De agenten werden gecontroleerd door de brigadiers. Deze laatsten stonden onder het toezicht van de hoofdbrigadier en de adjunct-commissaris die werkte op het middenbureel.

De commissarissen daarentegen werden gecontroleerd door de gemeentelijke overheid en de hoofdcommissaris.

De verslagen van de overtredingen of het onachtzaam uitoefenen van de taken werden via de hoofdcommissaris overgemaakt aan de gemeentelijke overheid. De hoofdcommisaris gaf hierbij advies over de te nemen tuchtmaatregelen (zie verder). ${ }^{22}$

Per trimester werd een 'Etat de renseignement sur la manière dont les commissaires de police s'acquittent de leurs devoirs' van de burgemeester naar de gouverneur gezonden. De gouverneur stuurde dit rapport door naar de minister van binnenlandse zaken. In dit rapport werden inlichtingen gegeven over de commissarissen. Inlichtingen zowel over hun geboortedatum, -plaats en vergoeding als over hun gedrag. De burgemeester vulde meestal enkel een beoordeling over hun gedrag in. Zowel de goede als de slechte punten werden beoordeeld. Wanneer bijvoorbeeld een commissaris zijn taak niet goed vervulde dan kon men in het volgende rapport lezen of hij nog verslechterd was of er verbetering merkbaar was. ${ }^{23}$

\section{B.1.2.3. Algemene diensten van de stedelijke politie}

\section{De markten en toneelzalen}

De gewone dienst voor het toezicht op de markten en de vertoningen werd geregeld door het gemeentebestuur. De hoofdcommissaris controleerde deze

21 Algemeene onderrichtingen, voor officieren en agenten van politie der stad Gent. 1868, pp19- 21. (Universiteitsbiblioteek Gent)

22 Ibidem. pp.23-25.

23 P.A.G. Provinciaal bestuur Oost-Vlaanderen n ${ }^{\circ} 260$. De rapporten dateren van 1851 tot 1863. Er waren geen andere te vinden. 


\section{VANDEWALLE}

dienst telkens hij het nodig achtte. Het hele korps nam deel aan deze dienst, ook de brandweer. De bevelen werden door de hoofdcommissaris gegeven. ${ }^{24}$

\section{De dienst van de reispassen}

Deze dienst hield het toezicht op de registers van de hotelhouders, herbergiers en logementshouders in. De controle werd in elke wijk uitgevoerd door de adjunct-commissaris. Elke dag moest de adjunctcommissaris in dergelijke etablissementen inlichtingen over vreemdelingen inwinnen. De informatie werd op een speciaal daarvoor bestemde lijst genoteerd. De lijst werd door de commissaris overgemaakt aan het middenbureel waar een algemene lijst werd opgemaakt. ${ }^{25}$

\section{De rijtuigen}

Het toezicht op de rijtuigen werd uitgeoefend door de adjunct-commissaris die dienst deed op het middenbureel. De adjunct-commissaris controleerde samen met de daarvoor aangestelde keurders of bij de exploitatie van de rijtuigen de reglementering op het vlak van reinheid en stevigheid werd gerespecteerd. Zij waakten ook, samen met de politie van de wijken, over de kledij en het gedrag van de koetsiers en traden op waar nodig was. ${ }^{26}$

\section{B.1.2.4. De gemeentegevangenis}

De personen die in de gemeentegevangenis zaten ter beschikking van de gerechtelijke overheid, werden door de politieofficieren van het middenbureel overgebracht naar het parket van de procureur des Konings. Samen met de gedetineerden werden de stukken en de processen-verbaal overgebracht. Elke dag bezocht dezelfde officier van politie de gemeentegevangenis en ondervroeg de gearresteerden (behalve zij die ter beschikking stonden van de gerechtelijke overheid). Hij controleerde het register van de opgeslotenen en gaf over alles een verslag aan de hoofdcommissaris. ${ }^{27}$

\section{B.1.2.5. De permanente dienst in het stadhuis}

De dienst van het bureel in het stadhuis werd uitgeoefend door een commissaris of een adjunct-commissaris van 09.00 uur tot 16.00 uur. Hij

24 Algemeene onderrichtingem, voor officieren en agenten van politie der stad Gent.pp 25.

25 Ibidem. pp.25-27.

26 Ibidem. pp. 27.

27 Ibidem. pp.27-29. 
werd bijgestaan door een brigadier, een agent en in sommige gevallen door de brandweer.

Zijn taak bestond uit het vaststellen van de op heterdaad betrapte misdrijven, het beteugelen van wanorde en hulp verlenen aan personen die beroep deden op de politie. Elke morgen om negen uur werd een verslag gegeven aan de hoofdcommissaris. In geval van misdaad of buitengewone gebeurtenissen werd de hoofdcommissaris onmiddellijk verwittigd. Hij moest de gemeentelijke overheid dadelijk op het hoogte stellen van verstoring van de openbare veiligheid, brand, samenscholingen... ${ }^{28}$.

\section{B.1.2.6 De wijkdienst}

De politiecommissarissen stonden in voor de dienst van de wijken. Zij waren ondergeschikt aan de hoofdcommissaris. De hulpwijken stonden onder het onmiddellijk bevel van de commissaris van de wijk waarbij ze hoorden.

De bevoegdheid van de commissarissen voor de wijken en van de adjunctcommisarissen voor de hulpwijken werd beperkt tot de grenzen van hun gebied. Ze stonden in voor het toezicht, het behoud van de orde en de uitvoering van wetten en reglementen inzake openbare gezondheid en veiligheid. Naast deze opdrachten werden ze belast met de bevolkingsregisters, het toezicht op de openbare onderstand(swoningen), het afleveren van getuigschriften van woonplaats, solvabiliteit, zedelijkheid,..., het opstellen van processen-verbaal van de commodo et incommodo en het geven van informatie over de militie en de burgerwacht. Deze taken zijn geen echte politie-opdrachten maar ze droegen bij tot het behoud van de orde en rust, de voornaamste taak van de gemeentepolitie. Elk wijk bestond uit verschillende kwartieren, die op hun beurt opgedeeld werden in seriën. Meestal werd één agent voor een serie aangesteld. ${ }^{29}$

De politiecommissarissen en de adjunct-commissarissen waren verplicht om in het midden van de wijk te wonen. De woonplaats van de andere officieren en agenten werd aangeduid door de burgemeester. ${ }^{30}$

De burelen van de politiecommissarissen bevonden zich in het midden van de wijk.

Wanneer er ernstige gebeurtenissen plaatsvonden moest dit onmiddellijk gemeld worden aan het middenbureel en aan de burgemeester.

Dagelijks moesten de commissarissen een tabel opmaken waarin de diensten van het personeel werden genoteerd en moesten ze een verslag van de gebeurtenissen geven. Vervolgens moesten ze lijsten maken van de personen die gearresteerd waren en van de vastgestelde misdaden en vergrijpen. Dit

\footnotetext{
28 Ibidem. pp. 29-31.

29 Ibidem. pp.21-23.

30 Organiek Reglement 1852 art. 5
} 


\section{VANDEWALLE}

alles werd overgebracht naar de hoofdcommissaris die het aan de burgemeester gaf. Na een maand of na drie maand werden ze overgemaakt aan de gouverneur. ${ }^{31}$

De hoofdcommissaris kreeg op 29 april 1853 o.a. volgend rapport in zijn bezit :

\section{Monsieur le commissaire en chef,}

J'ai l'honneur de vous faire connaître que deux contraventions ont été constatées, la première d̀ charge de Pierre Peirsegal, cabaretier, marché au grains $n^{\circ} 19$, pour avoir négligé, hier vers les 9 h du soir, d'éclairer sa lanterne; et la deuxième d̀ charge du nommé Charles Haecke, marchand de fibres, se disant demeurer à Ertvelde, s'étant permit d'entrer, avant l'heure, au marché aux poulets. Procés-verbaux de ces contraventions vous parviendront au plus-tót.

M. le commissaire de police Rottiers ${ }^{32}$

\section{De kwartieren}

De brigadiers-opzichters controleerden de agenten van dienst in de seriën. Wanneer er klachten waren, werd dit doorgegeven aan de hoofdcommissaris. Ze gaven inlichtingen over de gebeurtenissen in hun kwartier aan de wijkcommissaris.

\section{De seriën}

Een serie werd toevertrouwd aan een agent die, in deze omschrijving, de orde moest handhaven. De commissaris werd door de agenten ingelicht over de gebeurtenissen in de seriën. De agenten moesten de inwoners van hun serie persoonlijk kennen.

\section{De vaste posten}

In de belangrijkste straten en plaatsen werden permanente posten opgericht. De verschillende posten stonden met elkaar in verbinding om in geval van nood onderlinge hulp te kunnen verlenen en om de agenten vlugger en gemakkelijker samen te kunnen roepen. De dienst van de vaste posten begon om 10 uur. Al de agenten van de wijk namen deel aan deze dienst en werden om de drie uur afgelost. ${ }^{33}$

31 Algemene onderrichtingen pp 31-33.

32 S.A.G. Op.cit. Reeks R, n 357.

33 Algemene onderrichtingen pp. 35-37. 


\section{EEN ONDERZOEK NAAR DE ORGANISATIE VAN DE GENTSE POLITIE}

\section{Situering van de wijken}

In 1848 werd de stad ingedeeld in 5 politiewijken, in 1914 telde Gent 11 wijken. Gedurende die zesenzestig jaar kwamen er dus 6 wijken bij. De uitbreiding van het aantal wijken verliep meestal als volgt : de stad kende een uitbreiding doordat nieuwe woonwijken ingericht werden, doordat de industrie zich uitbreidde... Het gevolg was dat de wijken te groot werden voor één commissaris met een adjunct-commissaris en de agenten. Men kwam tot de opdeling van de wijk met een hulpwijk onder de leiding van een adjunct-commissaris. Doordat de bevolking verder toenam of het gebied zich nog meer uitbreidde werd het noodzakelijk om een nieuwe wijk op te richten. Zo kwam het dat de 11 wijken die Gent telde in 1914 niet allemaal nieuwe wijken waren maar vaak samengevoegde hulpwijken.

De eerste wijk strekte zich uit over het stadscentrum. De tweede wijk bestond uit de wijk van het Oud Begijnhof en de wijk van de Oude Houtlei. De wijk van de Oudburg en de H. Kerstwijk bestrijken het gebied van de derde wijk. Muinkmeersen en Overschelde situeerden zich in de vierde wijk. De vijfde wijk of St.-Pieters binnen de vroegere muren was het gebied rond het St.-Pietersplein. De zesde wijk werd gesitueerd rond de Brugse poort. De zevende wijk omvatte de wijk van het Spanjaardkasteel, de wijk rond de Antwerpse poort en de Heirnis.

Het handelsdok en de haven maakten deel uit van de achtste wijk.

De negende wijk strekte zich uit over de wijk van het park en St.-PietersAaigem. Het Rabot en de Blaisantvest maakten deel uit van de tiende politiewijk. De elfde en laatste wijk bestond uit Ekkergem en de Bijlokewijk. De vijf politiewijken die men kende in 1848 waren gelegen in het oude Gent. Iedere wijk en buurt kende zijn typische eigenschappen (het noorden werd bepaald door de haven en industrie, het oosten door het ooststation en het slachthuis...) met een specifieke bebouwing. Inzake het uitzicht van de huizen, die een beeld geven van de sociale klasse van de bewoners, kan men stellen dat het centrum en directe omgeving (de vijf eerste wijken) gekenmerkt werd door burgershuizen in de hoofdstraten en arbeidershuizen en beluiken in de zijstraten. Dit kwam eveneens voor in de andere wijken maar toch kon men daar echte arbeiderswijken onderscheiden, vb. de wijk van Dok en Muide of echte residentiewijken zoals de buurt rond het St.Pietersstation. ${ }^{34}$

\section{B.2. De benoemingen}

Het tweede hoofdstuk van het reglement behandelde de benoemingen.

Om de titels en bekwaamheden van de postulanten voor commissaris, adjunct-commissaris en politieagent te onderzoeken werd een commissie

34 DUMONT (M.E.), Gent, een stedenaardrijkskundige studie. Brugge, 1951. 


\section{VANDEWALLE}

door de gemeenteraad ingesteld. Deze commissie bestond uit de burgemeester, een schepen en drie gemeenteraadsleden.(art.8)

Voor 1849 werd het personeel van de politie eveneens benoemd door de gemeenteraad maar zonder dat de kandidaten werden doorgelicht.

\section{B.2.1 De procedure}

\section{De agenten}

De commissie onderzocht de kandidaten die solliciteerden voor de functie van politieagent.

Aangezien de gemeenteraad aan geen enkele overheid de goedkeuring moest vragen is er echter over de benoemingen van de agenten weinig informatie voorhanden. Overigens werd men pas als politieagent aanvaard na een jaar de dienst te hebben volbracht zodat de definitieve beslissing pas later werd genomen .

\section{De adjunct-commissarissen}

De personen die tot adjunct-commissaris werden benoemd waren niet alleen brigadiers of agenten van eerste klasse maar waren ook vaak afkomstig uit het leger of hadden reeds een administratieve taak vervuld. Bij de aanstelling van een adjunct-commissaris was de goedkeuring van de gouverneur noodzakelijk.

De procedure verliep als volgt : in een gemeenteraadszitting werd, op voorstel van de commissie, over een bepaalde kandidaat gestemd.

Nadat de stemming verlopen was en de kandidaat aangeduid was, stuurde de burgemeester een brief, met een zeer korte beschrijving van de kandidaat, naar de gouverneur. In de brief werd aan de gouverneur gevraagd om zijn goedkeuring aan de benoeming te verlenen. Bij vele benoemingen van adjunct-commissarissen zat er ook een brief bij die afkomstig was van de procureur-generaal of van de procureur des konings waarin de instemming met de benoeming werd meegedeeld.

Wanneer de gouverneur de aanstelling goedkeurde -ik heb geen enkele brief gevonden waarin hij het besluit van de gemeenteraad afkeurde- werd zijn beslissing aan verschillende personen meegedeeld. Vooreerst werden de burgemeester en schepenen van de stad Gent op de hoogte gebracht, maar ook de procureur des konings van Gent, de vrederechters van de twee Gentse cantons en de kapitein van de nationale gendarmerie.

Dat de procureur en de vrederechter van de benoeming op de hoogte werden gebracht, was niet verwonderlijk aangezien de adjunct-commissaris ook een gerechtelijke taak te vervullen had.

Vervolgens legden de adjunct-commissarissen de eed af in de handen van de burgemeester. 


\section{EEN ONDERZOEK NAAR DE ORGANISATIE VAN DE GENTSE POLITIE}

\section{De commissarissen}

De goedkeuring van de benoeming van een commissaris werd door een hogere instantie dan de gouverneur verleend, meer bepaald de minister van Binnenlandse Zaken in naam van de Koning. De commissarissen werden namelijk benoemd met een koninklijk besluit.

$\mathrm{Na}$ de stemming over twee kandidaten stelde de burgemeester deze voor aan de gouverneur. De burgemeester kon er zelf een derde kandidaat aan toevoegen, maar over het algemeen gebeurde dit niet. De gouverneur zond de informatie door aan de minister van Binnenlandse Zaken met het verzoek zijn goedkeuring te verlenen. De benoeming werd vervolgens vastgelegd in een Koninklijk Besluit.

Evenals de andere moest de commissaris nu de eed afleggen in de handen van de burgemeester. De formule van de eed was vastgelegd in het decreet van 20 juli 1830 en bestond uit de volgende woorden : 'Je jure fidélité au Roi, obéissance à la Constitution et aux lois du peuple belge'. ${ }^{35}$

\section{B.2.2. Aanwervingsvoorwaarden}

De eisen die gesteld werden voor elke functionaris van de administratieve of juridische politie waren de volgende : men moest naast een goede conditie beschikken over onderwijs en de nodige intellectuele bekwaamheden, meer dan 21 jaar oud zijn en voldaan hebben aan de wetten van militie, genieten van alle burgerlijke en politieke rechten, van goede wil en zeden zijn en onberispelijke antecedenten hebben. ${ }^{36}$

Om tot commissaris te kunnen worden benoemd moest men Belg zijn door geboorte of genationaliseerde Belg. De leeftijd voor een commissaris was deze van de de meerderjarigheid in de gemeente, $\mathrm{nl}$. 21 jaar.

De burgemeester, de schepenen en gemeenteraadsleden, de leden van de Bestendige deputatie, de leden van de rechterlijke macht en de notarissen en procureurs konden niet benoemd worden tot commissaris.

Naast deze officiële gegevens kan men afleiden uit de aanbevelingsbrieven dat belang gehecht werd aan ijver, inzet, intelligentie, correctheid...

Deze brieven waren enkel voorhanden bij de benoeming van het hoger kader maar dezelfde eisen werden waarschijnlijk ook gesteld aan de agenten.

In de loop van de jaren werden eveneens enkele eisen van de Gentse overheid schriftelijk vastgelegd.

In 1873 stelde Julius Vuylsteke (liberaal) voor op de gemeenteraadszitting van negentien juli dat de commissarissen en adjuncten de beide landstalen moesten beheersen. Hij eiste dat wanneer een proces-verbaal werd opgesteld dit in de taal moest gebeuren van de partijen. Dit voorstel werd niet zozeer

35 Pandectes belges. deel 20, 1886, pp 1053.

36 Ibidem. pp. 1054. 


\section{VANDEWALLE}

gelanceerd om een beter tweetalig personeelsbestand uit te bouwen dan wel om misverstanden te voorkomen. Vuylsteke vond dat men als ambtenaar zo getrouw mogelijk de woorden van de betrokkenen moest weergeven. Dit voorstel kwam naar aanleiding van een voorval. Wat er gebeurd was, werd niet door Vuylsteke vermeld, maar uit de tekst kan men afleiden dat het ging om de zaak Coucke en Goethals of de zaak-Schoep. In de maand waarin Vuylsteke zijn voorstel deed was men in de Kamer bezig het wetsvoorstel te onderzoeken op het gebruik van het Nederlands in het strafgerecht in Vlaanderen. Vuylsteke's voorstel werd waarschijnlijk hierdoor beïnvloed. Het ontwerp van Vuylsteke werd in het politiereglement ingevoerd op 27 april 1874 met de volgende woorden : Niemand zal als kandidaat voor eene plaats van commissaris of adjunct-commissaris in aanmerking kunnen komen, indien hij niet door een examen bewezen heeft de beide talen machtig te zijn. De commissarissen en adjunct-commissarissen zullen gehouden zijn in hunne processen-verbaal alle klachten en verklaringen op te stellen in de taal waarin dezelve hun door de klagers en verklaarders zullen gedaan worden.' 37

In 1902 werd door de gouverneur de regeling van de examens vastgelegd. Reeds vroeger dan die datum werden er examens voor bepaalde plaatsen uitgeschreven maar nu werd bepaald dat alle kandidaten voor de openstaande plaatsen van veldwachter tot commissaris een examen moesten afleggen. De gouverneur stelde dat het dikwijls gebeurde dat de gemeenteraden kandidaten kozen die niet over de vereiste voorwaarden (nodige onderwijs en lichamelijke hoedanigheden) beschikten, met als gevolg dat men tot nieuwe voorstellingen moest komen, wat vertragingen teweeg bracht, die in het belang van de openbare veiligheid te vermijden waren.

Het examen zou bestaan uit het lezen en het opstellen van een verslag en de vier hoofdregels van het rekenen. Voor de kandidaten commissaris en adjunct-commissaris zou het examen daarenboven enkele vragen bevatten over het bestuurlijk recht, het strafwetboek en het wetboek van strafvordering inzake de uitoefening van hun taken. Ze zouden ook een rekenkundig probleem moeten oplossen (o.a. de kennis van breuken).

De gouverneur voegde er aan toe dat zijn bestuur zich zou verzekeren of de aanvragers over de lichamelijke vereisten beschikken. ${ }^{38}$

Als men de informatie over de kandidaten bekijkt dan valt het op dat velen voor ze toetraden tot het Gentse politiekorps reeds in die branche hadden gewerkt. Behalve degenen die administratieve jobs uitoefenden (boekhouder, bediende bij de gemeentebelastigen..) waren er veel gendarmes, nachtwakers en brandweerlui die politieagent werden.

37 Gemeenteblad. 1873, pp. 575-578.

38 R.A.B.W. Op.cit. n' 2/8745/2. 


\section{B.3. Lonen en vergoedingen}

Het derde hoofdstuk van het reglement staat in het teken van lonen en vergoedingen. In het reglement worden echter alleen de lonen zelf weergegeven. Deze lonen werden gedurende de periode 1848-1914, zoals men wel kan verwachten, veranderd en aangepast aan de noden van de tijd.

De gemeentewet vermeldt dat de gemeenteraad moet instaan voor het salaris van de commissarissen en agenten van politie. ${ }^{39}$

\section{De politiecommissaris 40}

Het loon van een commissaris, vastgesteld in de gemeenteraad, werd vastgelegd in een koninklijk besluit. Dit koninklijk besluit kon enkel met de toestemming van de koning gewijzigd worden. Er werd een minimum en maximum loon voorgesteld met daartussen een aantal graden. Het loon mocht niet verdeeld worden in verschillende fracties, maar moest bestaan uit een globale som. Naast het loon kreeg de commissaris ook vergoedingen. Er werd een onderscheid gemaakt tussen de vergoedingen die werden uitbetaald voor het verlenen van bepaalde diensten en de onkosten ( $v b$. het bevolkingsregister, de kleding, bureelkosten ) en de toelagen die werden gegeven aan de commissarissen die een taak met ijver hadden volbracht. De eerste soort vergoeding kon de gemeente niet intrekken.

Aan de commissarissen werd het niet altijd toegelaten om buiten hun dienst iets bij te verdienen. Een aantal beroepen waren taboe omwille van het feit dat men bij de uitoefening van dergelijke bedrijvigheid een commissaris zou kunnen beschuldigen van partijdigheid. Het was verboden handel te drijven in dranken en levensmiddelen. Het werd ook raadzaam geacht dat de vrouw van een commissaris geen handel dreef. Dit zou het prestige van en het vertrouwen in de commissaris kunnen ondermijnen. Gezien het onmogelijk was voor de wetgever om een lijst op te stellen van de 'verboden beroepen' werd aan de gemeenteraad de verplichting opgelegd om streng toezicht te houden op de cumuls en deze te verbieden wanneer het misbruiken tot gevolg had. De commissaris had dan de keuze om ofwel bij het korps te blijven ofwel verder handel te drijven. Wanneer het bedrag werd vastgesteld vond men het daarom belangrijk dat de functionarissen een loon uitgekeerd kregen dat hen in staat stelde "te leven zoals het een commissaris past".

\footnotetext{
39 art. 131.5

40 Pandectes Belges. $\mathrm{n}^{\circ}$ 109, 1914, pp.1059-1064
} 


\section{VANDEWALLE}

Tabel I : Minimumjaarlonen 41

\begin{tabular}{llllllll}
\multicolumn{3}{c}{ agenten } & \multicolumn{7}{c}{ brigadier } \\
1852 & 700 & 675 & - & 800 & 750 & - & - \\
1860 & 825 & 800 & - & - & 910 & - & - \\
1867 & 925 & 900 & - & 1150 & 1000 & - & - \\
1895 & 1400 & 1350 & 1300 & 1700 & 1600 & - & - \\
1897 & 1470 & 1400 & 1300 & 1800 & 1700 & 1600 & 1550 \\
1903 & 1500 & 1400 & 1300 & 1900 & 1700 & - & -
\end{tabular}

Minimumjaarlonen: adj.comm.

commissarissen

$\begin{array}{llllll} & \text { max. } & \text { med. } & \text { min. } & \text { Hoofdcom. } & \text { com. } \\ 1852 & 1500 & 1200 & 800 & 4500 & 2700 \\ 1860 & 1200 & - & - & 4000 & 2700 \\ 1867 & 2000 & 1700 & 1400 & 4000 & 2700 \\ 1903 & 3300 & 2600 & 2300 & 7500 & 3700\end{array}$

De lonen werden ondermeer bij iedere grote aanpassing van het reglement in 1860 en 1867- veranderd. Ook in 1895 vond een grote loonaanpassing plaats. Deze verandering gebeurde voor het ganse lagere politiekader. Voor het eerst was er sprake van drie klassen van agenten die elk een bepaald salaris kregen. Men was agent van $3^{\circ}$ klasse tijdens de twee eerste dienstjaren, daarna kon men agent worden van $2^{\circ}$ klasse om tenslotte, na nogmaals twee dienstjaren te hebben vervuld, benoemd te worden tot agent van $1^{\circ}$ klasse. Deze regeling werd reeds in 1893 voorgesteld omdat men het eerlijker vond tegenover de ijverige agenten en deze die over een zekere anciënniteit beschikten. ${ }^{42} \mathrm{Bij}$ de lonen van de brigadiers ziet men dat een aantal keren een graad van brigadier wordt bijgevoegd of weggelaten. Constant aanwezig zijn de hoofdbrigadier en de wijkbrigadier.

De verschillen tussen de lonen van het hogere met deze van het lagere politiekader vallen onmiddellijk op. Wanneer in 1852 een $1^{\circ} \mathrm{klasse}$ agent $700 \mathrm{fr}$ en een hoofdbrigadier $800 \mathrm{fr}$ als jaarloon krijgen, ontvangt een adjunct van $1^{\circ} \mathrm{klasse} 1500 \mathrm{fr}$. Het maximum dat men als brigadier kon verdienen kwam min of meer overeen met de minima die de adjuncten ontvingen.

$\mathrm{Bij}$ de adjunctcommissarissen bleef het echter niet alleen bij deze jaarlonen want ze kregen een geldelijke vergoeding voor allerlei zaken.

In 1860 valt het op dat het bedrag lager is dan dat van 1852, maar men moet er nog een vergoeding bij tellen. Een adjunct die belast werd met de dienst in een wijk kreeg een premie van $400 \mathrm{fr}$. De adjunct, die als 'inspecteur de

41 De gegevens in verband met de lonen werden gevonden in de gemeentebladen

42 Gemeenteblad. 1893, pp.1157. 
service actif' dienst deed, kreeg $150 \mathrm{fr}$ extra. De adjunct-commissaris, die verbonden was aan het middenbureel, ontving een vergoeding van $300 \mathrm{fr}$ en de adjunct die belast werd met de sanitaire dienst verwierf er $300 \mathrm{fr}$ bovenop. In 1867 lagen de lonen dan weer hoger en kreeg enkel de adjunct die verbonden was aan het middenbureel een vergoeding van $300 \mathrm{fr}$.

De adjuncten van de hulpburelen kregen een gratis woning ter beschikking en hun bureelkosten werden op $250 \mathrm{fr}$ geschat, in 1903 op $350 \mathrm{fr}$.

In 1903 werd eveneens vastgesteld dat de adjuncten jaarlijks 175 fr mochten ontvangen voor hun kleding.

Opvallend is ook het grote verschil tussen de lonen van de commissaris en deze van de adjunct-commissarissen.

Er moeten nog enkele opmerkingen worden genoteerd gezien het gaat om de minimumlonen.

In $1852 \mathrm{kreeg}$ een hoofdcommissaris een groot loon in vergelijking met de andere jaren. De wijkcommissaris ontving naast $z$ 'n loon ook een vergoeding van 800 fr waarmee hij de bureelonkosten betaalde.

In 1860 en in 1867 verdiende de hoofdcommissaris evenveel als een commissaris maar hij kreeg een supplement van $1300 \mathrm{fr}$. De wijkcommissarissen ontvingen nog altijd $800 \mathrm{fr}$ voor de bureelbenodigdheden.

De toestand in 1902 was veranderd (sedert 1867) want men verdeelde de lonen onder in klassen. Een hoofdcommissaris verdiende minimum 3500fr, na 4 jaren dienst kreeg hij $4000 \mathrm{fr}$, na 9 jaren dienst $4400 \mathrm{fr}$.

Hij ontving daarbovenop een vergoeding van $2950 \mathrm{fr}$ maar kreeg geen bijdrage voor woning en de bureelkosten.

Een commissaris had als minimumwedde $3500 \mathrm{fr}$, hij kon dit na 4 jaar dienst optrekken tot $4000 \mathrm{fr}$ en kon na 9 jaren dienst het maximumloon van $4400 \mathrm{fr}$ in ontvangst nemen. Hij kreeg een vergoeding voor de bureelkosten en woonde gratis.

Voor de hoofdcommissaris werd het minimumloon in 1903 opgetrokken tot $7500 \mathrm{fr}$, het medium tot $8000 \mathrm{fr}$ en het maximum tot $8500 \mathrm{fr}$.

De commissarissen konden genieten van een minimumwedde van 3700fr, een medium van 3900 tot 4300 en een maximum van $4750 \mathrm{fr}$.

De gratis woning en de vergoeding voor de bureelkosten bleven van kracht voor de wijkcommissarissen.

Om nu te kunnen genieten van een hoger loon moest men toestemming vragen aan de gemeenteraad. Deze goedkeuring moest altijd gevraagd worden ook al had men het aantal jaren dienst vervuld.

De lonen van het politiepersoneel werden dus in de loop van de periode verhoogd. Ze konden aangevuld worden met verschillende soorten vergoedingen, vergoedingen die kosten dekten (bureelkosten, kledij..) en vergoedingen die werden toegekend omwille van buitengewone opdrachten. Er is een groot verschil vast te stellen tussen het salaris van het lagere en het salaris van het hogere kader. Dit is gedeeltelijk te verklaren door het feit dat, 


\section{VANDEWALLE}

wanneer men tot adjunct werd benoemd, men reeds een aantal jaren dienst telde of een zekere scholing had.

Binnen het hogere kader verschilden de lonen van de adjuncten eveneens sterk van de lonen van de commissarissen. Deze laatsten droegen immers een grotere verantwoordelijkheid. $\mathrm{Zij}$ stonden in voor een hele wijk en verdeelden het werk onder hun adjumcten en agenten.

Zoals bleek uit het verbod op bijverdiensten voor de commissarissen (cfr. supra) betaalde men liever een waardig loon zodat een commissaris in staat zou zijn te leven, zoals het bij zijn functie paste. De hoofdcommissaris, de functie waarvoor de burgemeester jaarlijks een commissaris aanduidde, was de best betaalde bij de politie. Het hoofd van de politie had een zware opdracht te vervullen en verzorgde de contacten met verschillende instanties. Hij stond in de eerste plaats in contact met de burgemeester, daarnaast informeerde hij de gouverneur, de procureur-generaal en de procureur des konings. Dat die commissaris, die hetzelfde loon kreeg als een wijkcommissaris, een speciale vergoeding daarbovenop kreeg is in feite logisch. De grote loonverschillen konden dan wel door gemeenteraadsleden aangeklaagd ${ }^{43}$ worden en min of meer opgevangen worden door de invoering van het systeem van minimum- medium- en maximumwedde, ze bleven echter bestaan.

\section{B.4. Het uniform}

In het organieke reglement van de Gentse gemeentepolitie werd uiteraard ook aandacht besteed aan het uniform. Het uniform is namelijk het herkenningsteken voor de burger.

\section{De Commissarissen}

Het uniform van de commissarissen van de gemeenten met 5000 inwoners en meer, werd geregeld door het koninklijk besluit van 3 december 1839. Het uniform bestond uit een 'habit-frac', een broek en een vest in zwart laken. De jas, met rechte kraag, had negen zilveren knopen met het wapenschild, de leeuw van België, en met het opschrift : commissaire de police en de naam van de gemeente. Bij het uniform hoorde een Franse hoed met een zilveren koord. De hoed was versierd met een kokarde ${ }^{44}$, een band met een rand in de nationale kleuren en een wapenschild.

43 Ondermeer in de gemeenteraadszittingen in 1902 door de heer De Bruyne en Bar.

44 Kokarde : onderscheidingsteken, gewoonlijk in de vorm van een strik, rozet of ovale knop, in de nationale kleuren aan het hoofddeksel gedragen. 


\section{EEN ONDERZOEK NAAR DE ORGANISATIE VAN DE GENTSE POLITIE}

De commissaris die door de burgemeester tot chef was benoemd, had een zilverkleurige rand op zijn hoed. ${ }^{45}$

In 1859 verscheen een nieuw koninklijk besluit waarin gesteld werd dat het uniform van de commissarissen mocht veranderd worden. Het uniform was als volgt samengesteld : een 'habit-frac', zoals in 1839, met op de kraag geborduurde eike- en olijfblaadjes omrand met zilverdraad; een blauwe broek met een zilveren band van 4 centimeter breed; een zwarte das met witte bies; een Franse hoed met een zilveren koord, versierd met een nationale kokarde en een band in zwarte en gele zijde met een rode rand.

De hoofdcommissaris droeg hetzelfde uniform met dit verschil dat zijn hoofddeksel versierd was met zwarte pluimen en het borduursel op de kraag omkaderd was met een dubbele zilveren draad. ${ }^{46}$

Deze beide koninklijke besluiten werden nagevolgd in Gent. ${ }^{47}$ Of de Gentse commissarissen hun uitrusting wijzigden is niet duidelijk. Het KB van 1859 bepaalde namelijk dat men het uniform van 1839 mocht blijven dragen.

De commissarissen moesten zelf het uniform betalen. $\mathrm{Zij}$ droegen het uniform enkel in buitengewone omstandigheden (bijvoorbeeld bij ordeverstoringen) en wanneer de burgemeester daar bevel toe gaf.

$\mathrm{Zij}$ moesten wel altijd, tijdens de dienst, hun sjerp dragen. ${ }^{48}$

\section{De adjunct-commissarissen}

De adjunct-commissarissen betaalden ook zelf hun uniform.

Hoe dit uniform eruit zag kon ik pas vaststellen in 1891. Op verzoek van de adjuncten werd de samenstelling van het uniform, vier jaar later, lichtjes gewijzigd. De adjuncten wensten een uniform dat gemakkelijker zat en goedkoper werd. Ze verlangden ondermeer dat de overbodige versieringen werden afgeschaft. Het uniform van de adjunct-commissarissen bestond uit een koningsblauwe jas in officierenstof. De jas had een dubbele rij zilveren knopen en een rechte kraag. Aan weerszijden van de kraag werden eikeblaadjes met eikels verstrengeld in olijfbladen geborduurd. Het borduursel, dat bestond uit fijne zilverdraad, had een hoogte van 4 centimeter en een lengte van 7 centimeter.

De broek was gemaakt uit dezelfde stof als de jas.

De helm was van vilt en werd overtrokken in de koningsblauwe stof. Het wapenschild en het helmteken waren in nikkel. De naden van de kepie waren versierd met een zilverkleurig koord en het boordsel was zilverkleurig. De kinhouder bestond uit zwart leder.

\footnotetext{
45 Pasinomie $3^{\circ}$ serie $n^{\circ} 9,1839$ pp. 347-348.

46 Op cit. $n^{\circ} 29,1859$, pp.61.

47 Reglement 1852 art.15.

48 Reglement 1867 art.14.
} 


\section{VANDEWALLE}

De adjuncten droegen een zwarte kraag zoals de legerofficieren en een kapmantel in koningsblauwe stof. De mantel had een dubbele flanellen voering in hetzelfde blauw met binnenzakken ter hoogte van de borst en zakken aan de buitenkant op de dijen. De graad werd aangeduid op elke hoek van de kraag met hetzelfde borduursel als op de vest. De mouwen waren versierd met een zilveren bies.

Bij het uniform hoorden ook witte handschoenen van kastoor ${ }^{49}$, een driekleurige sjaal rond de lenden en een riem in zwart gelakt leder. Deze riem sloot men met een gesp die het wapenschild droeg. Verder had men nog een regenjas.

De wapens van de adjunct waren een revolver en een sabel met een stalen koker. Deze wapens, door de stad geleverd, bleven eigendom van de stad. De adjuncten stonden wel in voor het onderhoud en de herstellingen.

De vernieuwingen evenwel, waren ten laste van de stad. 50

\section{De brigadiers en agenten}

In tegenstelling tot de hogere officieren moesten de brigadiers en agenten, reeds van in de beginjaren, altijd hun uniform dragen. Ze kregen een vergoeding voor hun kledij. In de reglementen van 1852 en 1867 werd niet uitvoerig ingegegaan op de samenstelling van het uniform. Men vindt enkel de vermelding dat de brigadiers en de agenten een volgnummer op hun kraag moesten dragen. De samenstelling van de uitrusting werd ondermeer bepaald door een resolutie uit $\mathbf{1 8 5 8}$. In 1885 werd deze resolutie lichtjes gewijzigd. De wijzigingen betroffen het uniform van de nachtwacht (zie verder) en het hoofddeksel. Het hoofddeksel vormde een belangrijk punt op de agenda van de zitting van 1 juli 1885. De burgemeester was van mening dat het huidige hoofddeksel onvoldoende bescherming bood tegen kwetsuren die de agenten konden oplopen als met stenen naar hen werd gegooid. Hij wou dat ze bij het uniform een sjako ${ }^{51}$ of een helm zouden dragen. De helm haalde het van de sjako en bestond uit vilt in koningsblauwe stof overtrokken. Het wapen- en helmteken waren in nikkel en het boordsel bestond uit twee zilverkleurige geborduurde biezen. De kinhouder was in mat zwart leder, vastgemaakt aan het hoofd van de leeuw in nikkel.

Naast deze helm droegen de agenten en brigadiers een jas in koningsblauwe wol met een dubbele rij knopen in nikkel. Ze beschikten over een broek in dezelfde stof en dezelfde kleur die lichtjes spande aan de pijpen en een broek in dril 52. Een kapmantel uit zware wollen stof, in het koningsblauw, behoorde eveneens tot hun uitrusting. De dubbel gevoerde mantel moest

\footnotetext{
49 Kastoor : beverhaar en het daarvan gemaakte vilt.

50 Gemeenteblad. 1891, pp 90-93.

51 Sjako : stijf, hoog, militair hoofddeksel in de vorm van een afgeknotte kegel

52 Dril : stevige linnen of katoenen gekeperde stof
} 


\section{EEN ONDERZOEK NAAR DE ORGANISATIE VAN DE GENTSE POLITIE}

plaats laten voor het handvat van de sabel en had, zoals bij de adjuncten, verschillende zakken. De agenten en brigadiers hadden een paar schoenen met een dubbele zool. Dit waren ofwel laarzen met grote elastieken en bovenleer uit één stuk of halve laarzen. Naast een zwarte kraag, regenkledij en en een gebreide zwarte sjaal hadden de agenten en brigadiers drie paar handschoenen. Een paar bestond uit gems, een ander uit zwarte wol en het derde paar uit floretzijde. De sabelhouder, in mat zwart leer, werd vastgemaakt aan een bruine lederen riem die werd ondersteund door een bretel.

Op het uniform werden de verschillende graden aangebracht. De agenten van eerste klasse onderscheidden zich van deze van tweede klasse door een ster genaaid op de kraag. Deze ster stond voor hun nummer.

Een brigadier kon men herkennen door het feit dat op de helm een derde bies werd aangebracht. Op de jas werden twee ineengestrengelde takken, een van de eik en de ander van de olijfboom, in zilvergaren op de kraag genaaid. Dit werd geplaatst na het nummer. ${ }^{53}$

\section{De bewapening}

De wapens maakten eveneens deel uit van de uitrusting. Hierboven werd reeds aangehaald dat de wapenuitrusting van de adjunct-commissarissen bestond uit een revolver en een sabel met een stalen koker.

$\mathrm{Bij}$ de brigadiers en agenten moest de kapmantel ruimte laten voor de sabel. In een discussie in het jaar 1887 over de aankoop van wapens werden de wapens van de verschillende leden van het korps vermeld.

De agenten en de brigadiers droegen een sabel met een lederen schede en een wapen van het systeem Colt, Amerikaanse makelij. De adjuncten beschikten ook over een sabel maar de schede was in staal. Er was discussie over het feit dat het Gentse gemeentebestuur wapens (van Amerikaanse corsprong) van Engeland hadden gekocht voor het politiekorps.

De Muynck (liberaal) begreep niet waarom men geen Luikse wapens had aangekocht die toch een internationale reputatie hadden. De burgemeester antwoordde dat de keuze van het college en de commissie vaststond aangezien de buitenlandse wapens ondermeer onder betere voorwaarden en prijs dan de Luikse konden geleverd worden. 54

De discussie kreeg een vervolg nadat de Luikse wapenindustrie, die het besluit van het college vernomen had via La Flandre. Liberale, een brief schreef. Hierin werd geprotesteerd tegen de door de burgemeester geuite beschuldigingen (ondermeer over de mindere kwaliteit van het ijzer dat in Luik zou gebruikt worden) die schade zouden toebrengen aan de Luikse belangen.

\footnotetext{
53 Gemeenteblad. 1885 pp 648-655, 665.

54 Gemeenteblad. 1887, pp. 15-19.
} 


\section{VANDEWALLE}

De Nobele (liberaal), lid van de commissie, was er nog altijd van overtuigd dat de Luikse wapens die ze getest hadden van een mindere kwaliteit waren. Er werd dan ook niets veranderd aan de genomen beslissing. 55

Het is overigens niet toevallig dat men in 1887 sprak over de aankoop van nieuwe wapens. In het rapport voorafgaand aan de zitting stond : 'Les regrettables événements dont notre ville a été récemment le théâtre ont démontré l'urgence de mettre la police à même de se protéger dans l'éventualité du renouvellement des sévices graves, des attaques odieuses dont elle a été malheureusement l'objet de la part d'une population détestablement empoisonnée par des meneurs anarchistes, qui prêchent quotidiennement la révolte ouverte et la désobeissance d̀ la loi'.56

Elk jaar moesten de personeelsleden oefenen op de schietbaan waar ze 20 patronen op een afstand tussen de 20 en de 50 meter moesten afschieten.

\section{B.5. De discipline}

Het laatste hoofdstuk van het reglement behandelde de discipline en tuchtmaatregelen. Het eerste artikel herhaalt de hiërarchische structuur die reeds voorkwam in het eerste hoofdstuk (Hoofdcommissaris, commissaris, adjunct...).

Welke straffen kon men oplopen bij de overtreding van het reglement ?

Er was een soort hiërarchie van waarschuwing, berisping, afhouding op het loon tot opschorsing, tijdelijke of definitieve degradatie en ontslag.

De eenvoudige waarschuwing, de berisping, de afhouding van het loon en de schorsing werden door de burgemeester uitgesproken. Het college sprak zich uit over de tijdelijke of definitieve degradatie en ontslag.

Maar het ontslag van de commissarissen behoorde tot de bevoegdheid van de koning (art. 123 gem.wet).

De burgemeester kon de commissarissen en adjuncten schorsen voor een periode van maximum 15 dagen. Hij kon daarna wel de schorsing verlengen. De gouverneur moest op de hoogte gebracht worden van de schorsingen. (123en art 125). In het provinciaal archief kan men vele brieven betreffende schorsingen en ontslagen om redenen van dronkenschap, verwaarlozing van de taak, cabaretbezoek... lezen.

Wanneer men een straf opliep werd dit genoteerd in de staat van dienst waarbij de overtredingen worden vermeld. Deze registratie kon, bij besluit van het college, ook geschrapt worden.

\footnotetext{
55 Ibidem., 1887, pp. 31-36.

56 Ibidem. 1887, pp.16.
} 


\section{DE NACHTWACHT}

Hoewel de nachtwakers deel uitmaakten van het Gentse politiekorps, behandel ik hen afzonderlijk omdat zij over een eigen reglement beschikten. Het reglement werd onderverdeeld in vier hoofdstukken. Het eerste hoofdstuk handelde over het personeel en haar bevoegdheden. Het tweede stelde de benoemingswijze en de lonen vast. Het derde deel beschreef de uitrusting en het vierde en laatste hoofdstuk gaf de disciplinaire straffen weer. ${ }^{57}$

\section{C.1. Het personeel en haar bevoegdheden}

Dat de nachtwacht behoorde bij de gemeentepolitie blijkt reeds uit de eerste artikels waarin men stelde dat een speciale categorie van politieagenten werd opgericht die de naam zou dragen van Nachtwakers (Gardes de nuit). Deze wakers moesten, zelfs overdag, ter beschikking staan van de politie, bij de eerste opeising van de hoofdcommissaris.

$\mathrm{Ze}$ werden ingedeeld in gewone wakers en brigadiers. In 1854 waren er tien brigadiers en zeventig gewone wakers. Twee jaar later werd het aantal gewone wakers teruggeschroefd naar zestig. In de wegwijzer noteerde men zestig nachtwakers zonder de vermelding van de brigadiers. Deze zestig werden in 1860 met 20 vermeerderd die geplaatst werden in de buitenwijken van de stad en de functie van brigadier werd opgeheven. Gent beschikte over tachtig nachtwakers tot 1875 . In de wegwijzer kan men het stijgend aantal nachtwakers volgen, namelijk : van 90 in 1876 tot 95 in 1881, 98 in 1883, 102 in 1884, 103 in 1888, 105 in 1892, 107 in 1897, 109 in 1899 om vanaf 1905 tot 1914 een constante te behouden van 111 wakers. $^{58}$

De nachtwacht werd in 1854 ingedeeld in vijf afdelingen die verbonden werden met de vijf politiewijken. De uitbreiding van de politiewijken zal ook gepaard gaan met de uitbreiding van de afdelingen.

Elke wijk werd verdeeld in een aantal posten volgens de uitgestrektheid van het gebied. Een garde werd in elke post aangeduid voor het toezicht. De verschillende posten werden met elkaar in verbinding gesteld zodat men zich vlug kon verenigen als dit nodig zou zijn.

Alle wakers werden belast met de handhaving van de openbare riust, de veiligheid van de personen en het respect voor het bezit.

De brigadiers moesten de posten van hun wijk inspecteren en verzekeren dat de dienst regelmatig en met de nodige waakzaamheid verliep.

57 Gemeenteblad januari 1854.

58 In het gemeenteblad werd weinig aandacht besteed aan de reden van deze kleine uitbreidingen. 


\section{VANDEWALLE}

De dienst werd ingesteld van 1 september tot 30 april en begon om tien uur 's avonds om te eindigen om zes uur's morgens.

Elke morgen om elf uur moesten de wakers zich begeven naar de commissarissen van hun respectievelijke wijken en een mondeling verslag geven van de gebeurtenissen van de afgelopen nacht. De commissarissen moesten onmiddellijk tussenkomen waar het nodig was en de eventuele interventie vermelden in hun dagelijks rapport.

De leiding en het toezicht op de nachtwakers was in handen van de hoofdcommissaris die handelde in opdracht van de burgemeester.

\section{C.2 De benoemingen en de lonen}

De benoeming van de nachtwakers werd toevertrouwd aan het College van burgemeester en schepen. Bij de nachtwakers werden eveneens sollicitatiebrieven geschreven. De sollicitanten waren laag geschoold. Dit blijkt ondermeer uit deze brief gericht aan het college 59: 'Ik smeek U, Mijnheeren, indien er eenige mogelijkheid bestaat mijn nederig verzoek (om als nachtwaker benoemd te worden) in te willigen, des te meer daar ik mijn in eenen zeer netiligen toestand bevind ten gevolge van het stilvallen des Werkhuizen, alwaer ik als borstelmaker werkzaam was'.

Deze brief van August De Vreese werd geschreven in april 1881.

Er werden waarschijnlijk geen hoge eisen gesteld, aangezien een mondeling verslag van de gebeurtenissen aan de commissaris volstond kan men er van uitgaan dat kunnen lezen noch schrijven vereist was. Als men vervolgens het loon bekijkt, ziet men dat de nachtwakers de slechtst betaalde personeelsleden waren van het korps, hoewel ze nachtdienst verrichten.

Jammer genoeg werd in het gemeenteblad praktisch niets geschreven over de loonsverhogingen bij de nachtwakers waardoor ik over geen gegevens beschik van de periode 1860 -1895 en na 1903.

Tabel II : De minimumjaarlonen van de nachtwakers

$\begin{array}{llll}\text { Jaartal } & \text { Brigadiers } & \text { Wakers } & \text { Agenten } \\ & & & \\ 1854 & 750 & 540 & 675 \\ 1856 & 800 & 600 & - \\ 1860 & - & 600 & 800 \\ 1895 & - & 900 & 1300 \\ 1897 & - & 950 & 1300 \\ 1903 & - & 950 & 1300\end{array}$

De lonen van de gewone wakers lagen duidelijk lager dan de minimumlonen van de agenten.

$59 \quad$ S.A.G.Op.Cit. Reeks R n 107 
Op het eerste zicht was er voor de nachtwakers geen loonstijging in 1903 maar doordat de lonen werden opgedeeld in minimum, medium en maximum, zoals bij de overige personeelsleden, vonden er wel degelijk veranderingen plaats. De bedragen werden vastgesteld op $950 \mathrm{fr}$ minimum, $1000 \mathrm{fr}$ medium en $1030 \mathrm{fr}$ maximum. De graden werden telkens na drie jaar dienst bereikt en het maximum na vier jaar medium.

De Brusselse nachtwakers hadden van 1909 tot 1911 een jaarloon van $910 \mathrm{fr}$. In 1912 werd dit met 5 fr opgetrokken en in de periode 1913-1915 ontvingen ze 1005 fr. Reeds in 1903 verdienden de Gentse nachtwakers meer dan de Brusselse. ${ }^{60}$

De nachtwakers waren duidelijk de minst betaalde groep die deel uitmaakte van het politiekorps.

\section{C.3. De uitrusting}

In 1854 werd het uniform als volgt samengesteld : een koningsblauwe jas met een broek in het kleur maringo, een zwart lederen riem met een plaat met de stadswapens, een hoed in gelakt vilt met de inscriptie 'Surveillant Garde de nuit $I^{\circ}$ ou Garde de nuit' $I^{\circ}$ en een mantel met kraag in een geimpermeabiliseerde stof.

In de winter droegen ze een kapmantel en een klein lantaarntje.

Toen in 1885 de uniformen van de politie werden aangepast, werden eveneens veranderingen aan het uniform van de nachtwakers doorgevoerd.

De nachtwakers droegen in 1885 hetzelfde uniform zoals beschreven werd bij de agenten maar ze beschikten niet over de floretzijde handschoenen. Het uniform werd afgebiesd met een rode versiering.

\section{C.4. De disciplinaire straffen}

Het vierde en laatste hoofdstuk somt de tuchtmaatregelen op. De kleinste straf bestaat uit een berisping, daarna komt het inhouden van het loon voor vijf, tien of vijftien dagen, de laatste en zwaarste straf was het onstlag.

De berisping en het inhouden van het loon konden opgelegd worden door de hoofdcommissaris. Het ontslag kon alleen uitgesproken worden door het College. Geen straf zou worden toegepast indien de nachtwaker niet gehoord werd.

Het geld dat werd verkregen door het inhouden van het loon werd gestort in een kas ten voordele van wakers die hun dienst omwille van ziekte niet konden uitoefenen. De wakers moesten immers hun vervanger zelf betalen.

60 VAN DEN EECKHOUT (P). Lonen van Brusselse arbeiders in openbare instellingen (1809-1934) : bouwvakarbeiders, ziekenhuis- en stadspersoneel. Brussel, 1979, p. 47. 


\section{VANDEWALLE}

In 1887 reageerde Cambier (radico-socialist) op deze wijze van werken. Hij vond het onaanvaardbaar dat men agenten niet hielp die tijdens hun dienst verongelukten. De burgemeester vond het plan van Cambier, $\mathrm{nl}$. de gemeente betaalt de vervangers van zieke wakers, niet realiseerbaar. Hij stelde dat men moeilijk kon vaststellen of de waker ziek was geworden door het uitoefenen van zijn dienst en vreesde dat de stad de dupe ging worden van ingebeelde ziekten of ongelukken. $\mathrm{Na}$ een lange discussie werd uiteindelijk niets beslist. $^{61}$

\section{C.5. De nachtwakers en politiehonden}

Een spectaculaire verandering in de organisatie van de dienst van de nachtwakers was stof voor vele kranten. In 1899 besloot de toenmalige hoofdcommissaris door de toename van de diefstallen en gezien er geen geld was voor nieuwe wakers, om politiehonden in te zetten bij de nachtwakers.

Acht jonge herdershonden gingen 's nachts mee op ronde. Zo werd Gent de eerste stad in de wereld die agenten liet vergezellen van honden. ${ }^{62}$

Voor dit fenomeen bestond enorme belangstelling. Haast in alle Belgische kranten verscheen een artikel over de Gentse politiehonden. Niet alleen Belgische kranten hadden aandacht voor de hulp van de honden, ook buitenlandse dagbladen zoals Le Figaro (15/12/1916) of The New York Tribune en Le Matin (18/03/1907) en tijdschriften als Review of reviews en The Independent hadden heel wat ruimte over voor deze primeur.

Naast de pers hadden ook andere korpsen interesse voor het gebruik van politiehonden. Commissarissen en gezanten kwamen van Rijsel, Poitiers, Bordeaux, 's Hertogenbosch, Breda, en zelfs van New York (de gezant nam vier honden mee). Een substituut van de keizerlijke procureur van de senaat van Finland was geinteresseerd en toen in Gent een Chinese zending op bezoek kwam, werd een demonstratie gegeven.

Dat het gebruik van honden navolging kreeg, kan men ondermeer lezen in de Gazette van Gent uit 1907 : 'Uit Amerika, waar ook het stelsel van de politiehonden is ingericht, is een brief ontvangen zeggende dat een der honden een belangrijke aanhouding heeft bewerkstelligd en dat men de hond daarom Gent genoemd heeft'.

\section{BESLUIT}

Het Gentse politiekorps kende een enorme professionalisering gedurende de behandelde periode. Er waren niet alleen algemeen organisatorische

61 Gemeenteblad. 15/02/1887, pp.67-71.

62 In Berlijn gebruikte men wel reeds honden, doch slechts om moorden op te lossen. 


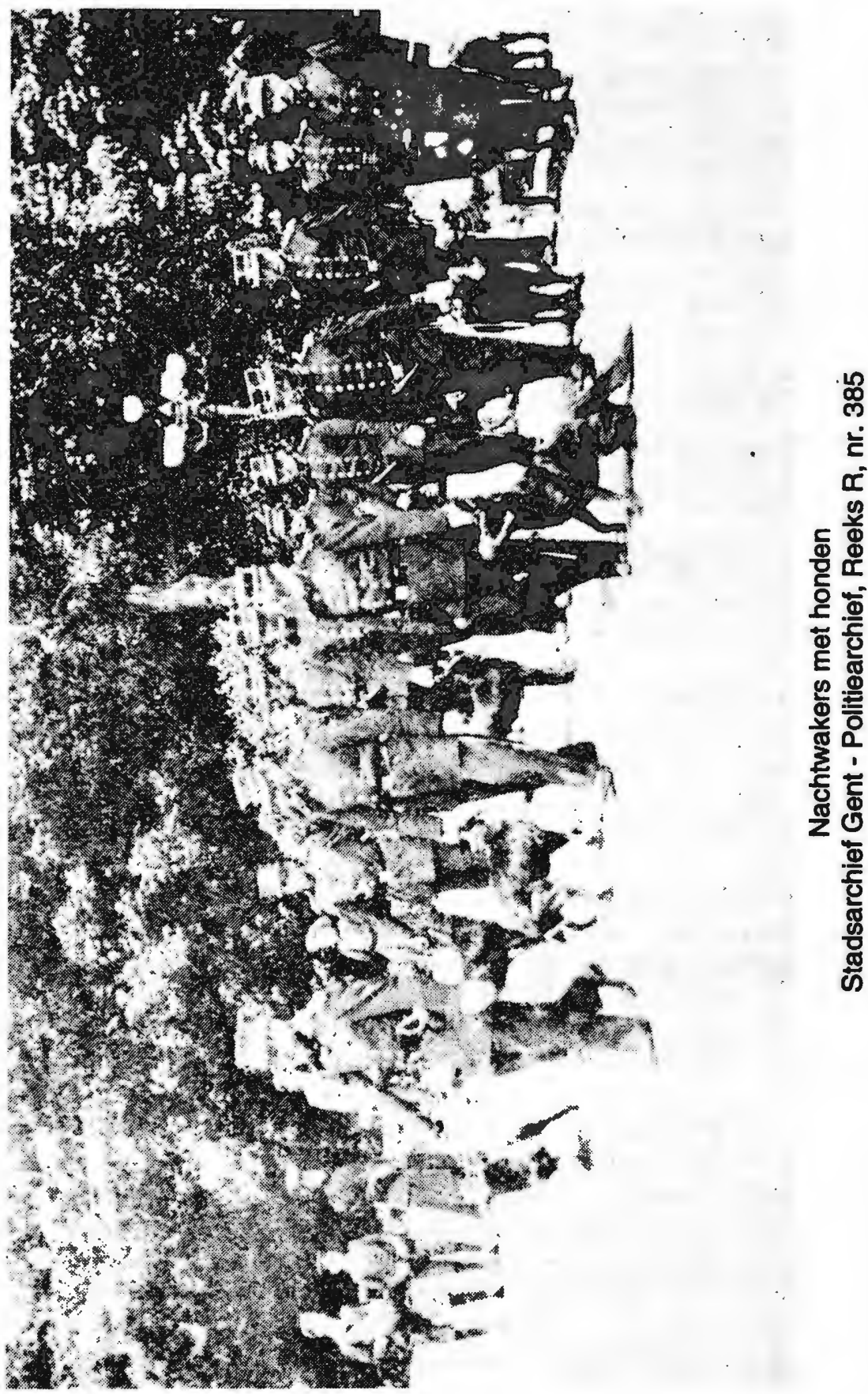




\section{VANDEWALLE}

veranderingen, maar ook werden er normen gesteld voor de sterkte, recruteringsvoorwaarden vastgelegd en werd er aandacht besteed aan de belangen van het personeel. Dit laatste geldt vooral voor de periode (vanaf 1894) waarin de socialisten in de gemeenteraad zetelden.

Men ziet een verbetering niet alleen van de kwantiteit maar ook van de kwaliteit.

De ordehandhaving werd in 1848 toevertrouwd aan een dertigtal personen. Dezelfde stad beschikte in de vooravond van de eerste wereldoorlog over een korps van 372 leden. Niettegenstaande het feit dat de uitbreiding geleidelijk gebeurde kan men drie momenten van grote extensie aanduiden. Meer bepaald 1848, 1860 en 1890.

De uitbreiding van het grondgebied en de stijging van de bevolking waren de voornaamste redenen om nieuwe leden tot het korps te benoemen. Deze verklaring gaat echter niet op voor de hierboven reeds genoemde ogenblikken van grote extensie.

In 1860 kwam de uitbreiding van het korps er door de afschaffing van de octrooien. Aangezien men aan de stadspoorten geen belastingen meer hief moest men op een andere manier toezicht kunnen houden over de toegangswegen tot de stad. De agitatie rond de kloosterwet en het optreden. van de politie hadden er niets mee te maken.

Zowel in 1848 als in 1890 kende het korps een uitbreiding onder druk van de oproerige bewegingen. In 1848 stond men zeer zwak en kon men de taak die door de overheid werd opgelegd zeker niet vervullen. Eind jaren tachtig. beschikte men echter reeds over een goed uitgebouwd korps. Toch werden veranderingen, zoals de invoering van het gebruik van vuurwapens, noodzakelijk geacht. In die periode kende men in België, en niet alleen in Gent, een groeiende socialistische arbeidersbeweging.

Er braken enkele stakingen uit maar de situatie kon onder controle worden gehouden. De uitbreiding van het korps kwam waarschijnlijk ook onder nationale druk tot stand.

Dit brengt ons op het vlak van de gemeentelijke autonomie. De gemeentelijke autonomie werd achterwege gelaten op de twee ogenblikken van oproer die ik van nabij bekeken heb. In 1848 was de rol van de politie miniem en bleef ze beperkt tot de dagelijkse taken en een verscherping op de controle van vreemdelingen. In de overheidscorrespondentie wordt haast niet gesproken over de gemeentepolitie. De belangrijkste rol in de repressie werd gespeeld door de gendarmerie. De gouverneur, de procureur des konings en de procureur-generaal hielden de situatie scherp in de gaten en berichtten de nationale overheid. Deze overheid gaf de bevelen. De reorganisatie na 1848 werd doorgevoerd op aanvraag van de minister van binnenlandse zaken en de minister van justitie, terwijl de burgemeester toch over de 'vrijheid' beschikte om ze te laten plaatsvinden zoals hij wou (maar wel met een 


\section{EEN ONDERZOEK NAAR DE ORGANISATIE VAN DE GENTSE POLITIE}

hoofdcommissaris en een adjunct per commissaris). Hier is de gemeentelijke autonomie ver te zoeken.

De repressie op de onlusten die men in Gent verwachtte in het jaar 1886 werd goed voorbereid. Dit gebeurde in samenspraak met de verschillende ordetroepen. Ook nu deed de gemeentelijke overheid wat door de nationale overheid werd opgelegd.

Op deze ogenblikken van onrust is het eigenlijk begrijpelijk dat de ordehandhaving door de nationale overheid werd georganiseerd. Waren de rellen in wezen geen fenomeen dat de strikt lokale belangen ver overschreed?

Behalve bij het repressiebeleid kwam de overheid praktisch niet tussen.

De beslissingen over de benoemingen werden eerst op lokaal vlak genomen, waarna de gouverneur en de minister (in geval van de commissarissen) hun toestemming moesten geven. In het archief ben ik geen enkel geval tegengekomen waarbij een kandidaat, door de gemeenteraad voorgesteld, werd afgekeurd.

De aanwervingsvoorwaarden waren weliswaar op provinciaal en nationaal vlak vastgelegd maar de uiteindelijke benoeming bleef in handen van de gemeentelijke overheid.

De lonen en de vergoedingen waren een puur lokale aangelegenheid.

Het uitzicht van het uniform kende dan weer nationale voorschriften maar de aankoop en verdeling bleef in lokale handen.

Gent kon zelf beslissen welk type van wapen men zou aankopen voor de agenten.

Inzake de discipline werden de meeste maatregelen genomen door de burgemeester. De zwaardere bestraffingen van commissarissen moesten wel hun goedkeuring krijgen van de hogere overheid.

Al deze zaken (aanwervingsvoorwaarden, lonen, uniform, bewapening) werden in de loop van de behandelde periode aangepast aan de noden van de tijd. Er werd gebruik gemaakt van nieuwe hulpmiddelen zoals de telefoon, honden en fietsen om het dagelijkse werk op een efficiëntere manier uit te voeren.

Algemeen kan men besluiten dat het Gentse politiekorps uitgroeide tot een volwaardige politiedienst. De burgemeester, hoofd van deze organisatie, kon zijn gezag laten gelden bij allerlei aangelegenheden behalve dan wanneer het, bestudeerde, oproer voortkwam uit nationale onvrede en op straat eisen werden gesteld die het lokale niveau overtroffen. 